\title{
INNOVATIVE METHODS IN POSTGRADUATE STUDENTS' TEACHING
}

The article is dedicated to the innovative methods in postgraduates' teaching as one of the top tasks of their professional education. The work presents a list of Ukrainian and foreign scientists who investigated the problem; sets the purpose, tasks, object, and subject of the research as well as the pedagogical conditions characteristic of the study; the theoretical and methodological background and the methods that were used when carrying out the experiment. A question of future international scholars' professional training and communicative competence they develop during the courses of "English for Specific Purposes" and "Academic English" which are the compulsory disciplines for all postgraduate students at Odessa National Academy of Food Technologies is also disclosed.

We look at interactive studying that includes a rich variety of types, forms and teaching techniques, and involves communicative cooperation and teamwork. A handbook of methodological recommendations "Business \& Academic English" for practical linguistic activity in English has been introduced. It is aimed at innovative teaching forms presentation and implementation and contain a wide range of interactive tasks based on the requirements to the style of the scientific English language altogether with lexical, stylistic and grammar peculiarities specific to the academic English of each specialty. Multimedia lectures and workshops as an effective modern way of future scientific staff teaching and training in addition to their positive methodological aspects are characterised too; a term "role play" is defined, its characteristics and features are examined.

The article dwells on a scientific role-playing game that was held at a foreign language workshop in the course of post-graduate studies at ONAFT. It reveals its components, purpose, details and the aim which was to stimulate the educational, cognitive, scientific and research activities of post-graduate students and form a new style of their linguistic behaviour and English communication. As for the content, the interactive lesson imitates the process of a real PhD thesis defence in a shortened and simplified format, and has three stages (preparatory, practical and analytical). The roles of the participants are shared according to their language lever.

Interactive teaching technologies develop students' communicative competence and academic English speaking skills creating favourable pedagogical and psychological conditions for future scholars' cooperation and research work.

Key words: innovative methods, interactive teaching, communicative competence, postgraduate students, role-plays, scientific games.

Introduction. One of the priority areas of postgraduate studies development in Ukraine in recent years has been the introduction of active and interactive methods and technologies into the educational process. A particular attention has been paid to their use in foreign languages teaching, as all the fields of scientists' activity nowadays feel the need for specialists who master communicative competence, speak fluent English and can interact independently in the scientific international environment.

Interactive studying is seen as a form students' common activity. Such means of conducting lectures involve communicative interaction and group experience reliance. They are characterized by a high degree of participants' intercourse intensity and a rich variety of types, forms, and educational techniques where all the members are engaged in knowledge, ideas, and activity exchange [2, p. 42].

Literature review. The professionally-oriented English language has been investigated by both

(C) Ogrenich M. A., 2020
Ukrainian and foreign scholars in various aspects: a method of students' lexical competence formation (V. Borshchovetsky, G. Hryniuk, Ch.Mallinson, Y. Semenchuk, L.Strickling), oral linguistic competence (D. Cotton, D. Falvey, I. Kamensky, S. Kent), monologue speech teaching (T. DudleyEvans, I. Fedorov, P. Robinson), oral and written business communication (D. Brinton, O. Bykonya, S. Donna, J. Lacina,), business presentations (Y. Avsiukevich, P. Emmerson, T. Hutchinson, C. Kennedy, O. Shevchenko), vocationally-oriented texts analysis (R.Kalamarz, T. Korzh, J.Michael, A.Waters), business letters and contracts writing (K. Allan, N. Bibik, R. Bruce, A. Fernkham, O. Pinchuk, N. Volkova), reference and information documentation organisation (K. Jones, J. Richards, G. Skurativska, M. Swain, N. Zinukova,), computerized reading (P.Greenwood, P. Radetzky), educational games and projects techniques (J. Brine, D. Bubnov, A. Bunin, T. Hutchinson, O. Kmit, O. Tarnopolsky, E. Zinnurov), innovative technologies in professional 
vocabulary mastering (T. Aslamov, M.Cotton, J. Cummins. T. Karaieva, Z. Korneva, M. Swain).

Discussion. The literature analysis led to a conclusion that modern methodology lacks a substantial analysis of specific research practice and verified examples of interactive technologies implementation into the course of foreign languages teaching in the process of future academic staff training.

This contradiction predetermined the topic and relevance of our research.

The aim of the article is to give a theoretical and practical analysis of the successful scientific roleplaying games use in postgraduate studies at a nonlinguistic higher educational institution.

The object of the study is the process of postgraduate training at Odessa National Academy of Food Technologies.

The subject of the study is scientific role-playing as one of the most effective interactive teaching methods.

The pedagogical conditions of the research are as follows: goals and objectives of postgraduate studying definition; methodological support for roleplaying games development; interactive approach.

The tasks of the work are: to study the pedagogical and methodological literature on postgraduate students' linguistic preparation; to develop theoretical and methodological basis for conducting scientific role-playing games; to determine the educational problems of the courses "English for Specific Purposes" and "Academic English"; to experimentally prove the developed methodology effectiveness.

To solve these issues, theoretical (pedagogical and methodological literature review) and empirical (observation, questioning, reports, interviews) methods were used and a pedagogical experiment was conducted.

Learning a foreign language is one of the most important components of future international scholars' professional training. Future academic staff's English communicative competence formation implies the development of monologue and dialogue speech skills necessary to take part in professional conferences and discussions. Therefore, the educational process organisation using interactive forms of teaching plays an important role in achieving the optimal results.

The disciplines "English for Specific Purposes" and "Academic English" at Odessa National Academy of Food Technologies which are compulsory for the postgraduate students of all specialties have ample opportunities for innovative interactive teaching methods introduction. They are aimed at future academic staff preparation to work at non-linguistic higher educational institutions both in Ukraine and abroad.

A considerate prerequisite for the effective use of innovative tools in a foreign language acquisition is the methodological recommendations for interactive teaching forms realisation. One of them is the use of "concentrated learning technology" which, firstly, allows to devote a lot of time to interactive cooperation, and, secondly, makes it possible to eliminate the time constraints that traditional classical higher education training imposes. Thus, we recommend to reduce the lecture room "formality" organising even the training space in another way (e.g. the students take their sits at a round table or opposite to each other). This creates an educational communication environment characterized by interplay, openness and collaboration of all the participants.

A handbook "Methodological recommendations for practical classes in English "Business \& Academic English" for postgraduate students of all specialties which were developed by us, present a wide range of interactive tasks based on the requirements to the style of the scientific (academic) English language. When fulfilling such exercises, the students exchange information and opinions on professionally-oriented articles; discuss the scientific topics, issues or ideas; express their view points on the basis of the acquired knowledge, thoughts or experience; make public speeches and presentations in English.

To develop the speaking skills, vocational situations that imitate scientific conferences or seminars were performed on one of the following topics: "Modern Trends in Management Development", "Information Systems Design", "Sales in Virtual Reality", "Molecular Sensors" and others. During the discussion, our post-graduate students learn to think critically, accept alternative messages and intentions, solve complex problems considering the circumstances and relevant data, communicate with colleagues and make progressive decisions. The handbook also provides vocabulary and stylistic resources specific to the academic English of each specialty.

Effective implementation and use of interactive teaching methods is impossible without multimedia devices.

We define the term "multimedia" as a computer technology that lets us present the content by a combination of various types of information: both static (text, graphics) and dynamic (animation, language, music, video). Multimedia is the only digital space that, in a syncretic form, represents different ways and types of information transmission [4, p. 530-531].

Multimedia lectures and workshops are usually held in specially equipped lecture rooms with powerful multimedia devices. The available advanced system enables speakers to deliver their material more efficiently influencing both the auditory and visual perception of the audience. Regarding the latter: interactive control on "smart boards" gives us an opportunity to introduce the usual display of any scheme or drawing in a more expanded form. 
The positive aspects of multimedia are interactivity, accessibility, and information saturation. They significantly increase motivation to study the disciplines based on a selective approach. Multimedia tools introduction gives a chance to systematise innovative methods according to the time limits and improve the quality of education in general [1, p. 4].

Methodology. An advantageous interactive way of future academic staff teaching and training with a possible and recommended use of multimedia means is a scientific role-playing game. Its purpose is to increase communicative competence and simulate diverse conditions for the research and professional activity.

By the term "a role play" we mean an interactive method of teaching which involves different life and work situations reproduction, and their subsequent analysis [7, p. 532]. A scientific roleplaying game is aimed at solving specific scientific, educational, and psychological problems; it always has a practical result and is characterized by a high degree of freedom. At the same time, it follows strictly defined rules, structure and time limits set by the presenter (in our case - a lecturer or moderator).

A scientific role-playing game is an indirect method of influence where the learner is a full-fledged subject of the activity which stimulates the self-knowledge and self-diagnosis processes. It forms creative abilities, develops attention, thinking, intuition, etc. and is a way of a personality socialisation; it also gives an opportunity to purposefully use speaking skills (in our case - the English language skills), and forms a new style of linguistic behaviour and foreign language communication.

Let's dwell on the examples of the scientific roleplaying games that are offered to be held at the foreign language workshops in the course of postgraduate studies at Odessa National Academy of Food Technologies.

For example, the "International Scientific Conference" game implies the following roles for its participators: the head, who makes opening and closing speeches and gives a word to the other members; a speaker with a prepared speech on his work and research (monologue speech skills are formed or improved); discussion partners who initiate talks (dialogue speech skills are formed or improved).

One of the variants of a scientific game is "The Doctoral Thesis Defence" when the scientific research defence in a foreign (English) language is modelled. One of the participants plays a part of a scientist who presents and defends his research paper, the others are the Academic Council members who ask questions, and opponents who characterise the work.

Let's look at the content, purpose and features of this game in detail.

The main idea of the scientific role-playing game "The Doctoral Thesis Defence" is to activate the postgraduate students' educational, cognitive, scientific and research activities.

The tasks of the game are the following: to generate interest in a foreign language learning during postgraduate studies, investigate the main goals and ideas of the training course; to increase curiosity and concern in lecturing and scientific research activity as a whole; to develop group communicative skills; to simulate the process of scientific research defence; to improve the public speaking skills of those who perform the roles of applicants, scientific advisors, opponents, and the Academic Council members; to expand and deepen the previously acquired knowledge in the disciplines "English for Specific Purposes" and "Academic English" and use their experience in context; to foster a responsible attitude to the social and communicative values of a scientific community.

The number of participants of a role-playing game can be that of an academic group (10-15 people); the duration is two academic hours (120 minutes).

As it was mentioned above, the role-playing game structure is a process of a real $\mathrm{PhD}$ thesis defence imitation. Its main stages are preparatory, practical (the game itself) and analytical.

The students are proposed various research topics, namely: "Prospects for Food Industry Development in Ukraine", "Product Quality and Safety Definition", "Physical and Chemical Foundations of Technology", "Enzymes. Their Technological Parameters", "Education System Information Security", "A Trade Enterprise Development Strategy", "Economic Modernisation Innovative Potential", "Hydrogen and Oxygen Flame Production", "Polar Magnetron Sputtering System Modelling" and others.

The methods to estimate the experiment efficiency were the following: questionnaires, interviews, reports, the invited scientific English speaking expert's overview, the final exam (the scientific role-play).

Let's dwell on the main stages of the game.

At the preparatory stage, the expediency of conducting scientific games (role-plays) and their frequency is determined. The productive work and mistakes correction is ensured by a system of interactive lectures that lets students play a certain part (applicants, opponents, a chairman and members of the Academic Council).

During the introductory step, the lecturer explains the importance, goals and tasks of the game as an example of an interactive teaching method that the tomorrow's scholars will be able to introduce into the educational process with their colleagues and students. It is also a kind of training and "rehearsal» of the forthcoming PhD thesis defence as it simulates the real scientific process and activates educational and cognitive work.

It is during the first section that the roles and topics of the research are shared; all the participants' 
regulations of interaction and collaboration are discussed and established; the requirements for writing and submitting reports or multimedia presentations are considered and approved. It should be noted that an informative Internet page dedicated to the lesson was created beforehand. It included the content, plan and rules of the game, the participants' characteristics, the workshop instructions, the speech topics and recommended literature list as well as online training and preparatory sources.

The practical stage - the game itself-involves the real $\mathrm{PhD}$ thesis defence simulation in front of the Academic Council in a shortened and simplified form.

At the analytical stage, the review of the whole educationaleventisconducted.Literacyand situational appropriateness of the foreign language use are characterised, the logic of the speech, the persuasiveness of the scientific research evidence base, the requirements for scientific reports and presentation are noted; the speech etiquette of academic English verbal and non-verbal communication is considered.

Results and conclusions. The outcomes of the experiment are as follows: scientific, systematic and conscious methodological, psychological and pedagogical knowledge and skills formation; interpersonal communication and public speaking experience extension; possible discrepancies between the theoretical and practical knowledge of a foreign language use elimination; communicative personal traits development; specialty-oriented reports and scientific multimedia presentations performance; professional, scientific and individual growth.

The results of the survey $(90 \%$ of the respondents gave a positive feedback) made it possible to conclude that scientific role-playing at foreign language classes helps post-graduate students to get prepared for their future thesis defence and professional academic career in general. It solves a lot of organisational, sociological, and communication issues, such as speaking skills improvement and audience management etc.

Moreover, this method is quite new in the process of foreign languages teaching and completely matches the educational trends of nowadays. It allows to define and settle the problems that postgraduate students face while studying as this type of work is quite complicated in content and calls for serious training.

The practical significance of our research is that the proposed scientific role-playing game can be used in further educational and teaching practice of postgraduate students not only while mastering the English language on the whole but during the course of their $\mathrm{PhD}$ thesis defence preparation and studying special professional subjects and disciplines.

The introduction of interactive technologies into the process of post-graduates' foreign language teaching at a higher technical institution, namely a system of scientific role-playing games, is an example of both lecturers and students' innovative activity. Such methods elaborate communicative competence and interaction, create a favourable pedagogical and psychological atmosphere in order to improve the future scholars' cooperation and academic English speaking skills. They allow to activate cognitive and research work, give an opportunity to demonstrate intellectual and scientific potential and personal position; serve as a training background for the real Doctoral thesis defence in English which completely responds to the challenges posed by international scientific societies to the future academic staff of the XXI century.

\section{References:}

1. Alaghmand S., Mozaffar F. Investigating Factors Affecting Students' Self-actualization at University Spaces. Revista Romaneasca pentru Educatie Multidimensio, 10, 2018. (Special Issue 1). P. 1-7.

2. Canale M., Swaine, M. Communicative approaches to second language teaching and testing. Applied Linguistics, 2010, \#1(1). P. 41-47.

3. Nambiar M., Hashim R. Impact of Integrating Local Culture Into Language Materials on Communicative Ability of Malaysian Lower Secondary Learners. The Southeast Asian Journal of English Language Studies, 2018, 24(4). P. 13-26.

4. Wen $Q$. The production-oriented approach to teaching university students English in China. Language Teaching, 2016, 51(4). P. 526-540.

\section{Огреніч М. А. Інноваційні методи в навчанні аспірантів}

Стаття присвячена новітнім методам викладання англійської мови в аспірантурі як одному з головних завдань профресійної підготовки майбутніх вчених. У роботі представлено перелік українських та зарубіжних вчених, які вивчали проблему; зазначено мету, об'єкт і предмет дослідження; а також необхідні педагогічні умови, теоретико-методологічну основу експерименту та методи, які використовувалися під час його проведення. Розглянуто питання профресійної освіти майбутніх науковців та їх комунікативної компетенції під час вивчення дисциплін «Англійська мова для конкретних цілей» та «Академічна англійська мова», які є обов'язковими курсами для всіх аспірантів Одеської національної академії харчових технологій.

Ми характеризуємо інтерактивне навчання, яке включає велику різноманітність типів, форм та методик викладення матеріалу і передбачає комунікативну взаємодію та групову роботу; 
наводимо методичні рекомендації до практичних занять з англійської мови «Ділова та академічна англійська мова», що спрямовані на впровадження інноваційних форм викладання та містять широкий спектр групових завдань з огляду на вимоги до стилю наукової англійської мови, а також лексичних ресурсів та стилістичного матеріалу, характерних для академічної англійської мови кожної спеціальності; даємо визначення терміну «рольова гра», розглядаємо його характеристики та особливості.

Мультимедійні лекції та інтерактивні практичні заняття як ефективний спосіб сучасного підходу до викладання англійської мови у процесі навчання майбутніх наукових співробітників загалом також відзначено позитивним методологічним результатом.

У статmі наводиться приклад наукової рольової гри, яка проводиться на практичному занятті з іноземної (англійської) мови в аспірантурі ОНАХT; визначається ї̈ зміст, деталі та ставиться мета - активізувати навчальну, пізнавальну, наукову та дослідницьку діяльність аспірантів та сформувати новий стиль їхньої мовленнєвої поведінки та спілкування англійською мовою. Щодо змісту, то інтерактивне заняття імітує процес реального захисту кандидатської дисертації у скороченому та спрощеному вигляді, модель якого складається з трьох етапів (підготовчий, практичний та аналітичний); ролі учасників розподілено відповідно до їх рівня володіння англійською мовою.

Інтерактивні технології навчання розвивають навички наукової (академічної) англійської мови та комунікативну компетенцію студентів взагалі, створюючи сприятливі педагогічні та психологічні умови для науково-дослідницької міжнародної роботи й англомовного професійного спілкування майбутніх науковців.

Ключові слова: інноваційні методи, інтерактивне навчання, комунікативна компетентність, аспіранти, рольові ігри, наукові ігри. 